\title{
PENGARUH IOS PADA NILAI PERUSAHAAN DENGAN KUALITAS LABA SEBAGAI VARIABEL MODERASI
}

\author{
Putu Eka Nopiyania ${ }^{\text {** }}$ Ni Made Wulan Sari Sanjaya ${ }^{\mathrm{b}}$, Ni Made \\ Rianita $^{c}$ \\ a,b,cSTIE Satya Dharma Singaraja, Jalan Yudistira Nomor 11, Singaraja, \\ Bali, Indonesia \\ *(nopiyanieka@gmail.com)
}

\begin{abstract}
ABSTRAK
Penelitian ini dilakukan untuk mendapatkan bukti empiris mengenai pengaruh investment opportunity set pada nilai perusahaan dengan kualitas laba sebagai variabel moderasi. Metode yang digunakan untuk menentukan sampel pada penelitian ini adalah teknik purposive sampling, sehingga diperoleh 38 perusahaan manufaktur sebagai sampel. Teknik analisis data yang digunakan dalam penelitian ini adalah Moderated Regression Analysis (MRA) dengan bantuan aplikasi SPSS 21 . Hasil penelitian ini menunjukkan bahwa investment opportunity set tidak berpengaruh pada nilai perusahaan. Kualitas laba mampu memperkuat pengaruh investment opportunity set pada nilai perusahaan.
\end{abstract}

Kata kunci: investment opportunity set; kualitas laba; nilai perusahaan

\begin{abstract}
This research is conducted to obtain empirical evidence about the effect of investment opportunity set on firm value with earnings quality as moderation variable. The method used to determine the sample in this study is purposive sampling technique, so that obtained 38 manufacturing companies as a sample. Data analysis technique used in this research is Moderated Regression Analysis (MRA) with the help of SPSS 21 application. The results of this study indicate that investment opportunity set has no effect on firm value. The earnings of quality are able to strengthen the influence of investment opportunity sets on the value of the firm.
\end{abstract}

Keywords: Investment Opportunity Set; Earnings Quality; Firm Value

\section{PENDAHULUAN}

Persaingan dunia usaha yang semakin ketat di era globalisasi saat ini menyebabkan dana yang tersedia dan juga sumber dana menjadi faktor utama yang mempengaruhi berkembangnya suatu usaha. Dana yang diperlukan tersebut umumnya didapatkan di pasar modal. Pasar modal dijadikan sebagai media tempat transaksi jual beli saham dan obligasi perusahaan, dan hasil dari 
penjualan akan digunakan perusahaan sebagai modal tambahan (Fahmi, 2012). Pihak perusahaan akan bertemu dengan pihak investor melalui pasar modal sehingga peran pasar modal dalam perekonomian suatu negara cukup besar. Tempat terselenggaranya kegiatan perdagangan efek pasar modal yang didirikan oleh suatu badan usaha di Indonesia disebut Bursa Efek. Berkembangnya bursa efek dapat dilihat dengan terus bertambahnya jumlah emiten yang terdaftar di bursa. Salah satu sektor industri yang tercatat di Bursa Efek Indonesia (BEI) adalah sektor industri manufaktur. Sektor industri manufaktur memiliki peran penting bagi masyarakat. Sektor ini bekerja untuk menghasilkan suatu barang yang sesuai dengan kebutuhan konsumen, dimana proses produksi dilakukan untuk mengubah bahan mentah menjadi barang siap pakai.

Manajemen perusahaan akan berusaha semaksimal mungkin untuk mendapatkan pendanaan demi perkembangan usaha perusahaan dengan cara menunjukkan kinerja yang baik kepada publik. Perusahaan yang memiliki kinerja yang baik akan sangat diminati oleh para investor. Salah satu aspek yang dapat digunakan untuk mengukur kinerja perusahaan adalah melalui laba perusahaan. Laba yang semakin tinggi menunjukkan bahwa kinerja perusahaan juga semakin baik.

Hasil kinerja yang baik akan menjadi pendorong utama bagi penciptaan nilai perusahaan. Para ahli keuangan mengatakan bahwa tujuan dari perusahaan adalah memaksimumkan nilai perusahaan karena semakin tinggi nilai perusahaan mengambarkan semakin sejahteranya pemilik perusahaan. Pernyataan tersebut juga didukung oleh theory of the firm yang menyatakan bahwa tujuan utama perusahaan adalah memaksimumkan nilai perusahaan (value of the firm) (Salvatore, 2011). Nilai perusahaan merupakan harga yang bersedia dibayar oleh calon pembeli apabila perusahaan tersebut dijual atau dapat diartikan sebagai harga pasar atas perusahaan itu sendiri (Husnan, 2000: 7). Salah satu hal yang juga menjadi pertimbangan investor dalam melakukan investasi adalah nilai dari perusahaan tersebut.

Keinginan yang besar dari pihak manajemen perusahaan untuk memperoleh sumber pendanaan melalui pasar modal dan keinginan untuk memaksimalkan nilai perusahaan inilah yang menjadi salah satu pemicu utama perusahaan melakukan discretionary accrual agar kinerja perusahaan terlihat baik atau 
bahkan sangat baik. Aktivitas discretionary accrual tersebut yang dapat berdampak pada tingkat kualitas laba perusahaan. Discretionary accrual nilainya ditentukan oleh kebijakan. Discretionary accrual memiliki hubungan yang terpola dengan aspek-aspek lain perusahaan seperti akrual total, pendapatan, piutang, dan plant, property, and equipment (PPE), tetapi ada sejumlah nilai discretionary accrual yang tidak cocok pola hubungannya dengan aspek-aspek tersebut. Kondisi tersebut dikenal dengan discretionary accrual abnormal yang sering digunakan sebagai proksi untuk menilai bahwa discretionary accrual telah dimanipulasi. Tujuan akhir manipulasi discretionary accrual tersebut adalah untuk memanipulasi angka laba sehingga hal ini dapat berpengaruh pada kualitas laba.

Pemikiran bahwa pihak manajemen dapat melakukan tindakan yang hanya memberikan keuntungan bagi dirinya sendiri didasarkan pada suatu asumsi yang menyatakan bahwa setiap orang mempunyai perilaku yang mementingkan diri sendiri (self interested behavior). Hal tersebut mengakibatkan terjadinya konflik dalam pengendalian dan pelaksanaan pengelolaan perusahaan, konflik yang terjadi akibat pemisahan kepemilikan ini disebut konflik keagenan. Konflik keagenan ini mengakibatkan pihak manajemen perusahaan melakukan praktik discretionary accrual. Discretionary accrual mengakibatkan informasi laba yang disajikan tidak sesuai dengan kondisi perusahaan, sehingga kualitas laba yang dihasilkan juga rendah. Rendahnya kualitas laba dapat menurunkan nilai perusahaan di pasar modal.

Laporan keuangan memiliki peran dan fungsi yang sangat penting bagi internal maupun eksternal dalam suatu perusahaan. Laporan keuangan merupakan sarana untuk mempertanggungjawabkan segala bentuk aktivitas yang dilakukan oleh manajemen atas sumber daya pemilik (Belkaoui, 1993). Tujuan laporan keuangan adalah menyediakan informasi yang berkaitan dengan posisi keuangan, kinerja, serta perubahan posisi keuangan suatu entitas yang bermanfaat bagi sejumlah besar pengguna dalam pengambilan keputusan ekonomi (SAK, 2012). Para investor dapat menilai kinerja perusahaan di masa yang akan datang melalui laporan keuangan, tetapi laporan keuangan yang baik tidak mampu menjamin bahwa kondisi riil keuangan perusahaan tersebut juga baik. Hal ini terbukti dari banyaknya laporan 
keuangan perusahaan-perusahaan ternama yang tidak dapat dipercaya kebenarannya akibat adanya skandal manipulasi keuangan perusahaan yang dilakukan oleh perusahaanperusahaan besar ternama tersebut.

Fenomena manipulasi laporan keuangan yang dilakukan oleh perusahaan-perusahaan besar dan ternama antara lain manipulasi keuangan Enron Corporation, PT KAI, PT Kimia Farma, dan lainnya. Fenomena tersebut merupakan bukti bahwa perusahaan yang menyajikan informasi dalam bentuk laporan keuangan yang baik dan memiliki nilai perusahaan yang baik juga tidak mampu memberikan jaminan bahwa perusahaan tersebut baik sesuai dengan kondisi perusahaan yang sebenarnya.

Salah satu skandal manipulasi keuangan lainnya yang baru-baru ini muncul adalah skandal yang dilakukan oleh perusahaan ternama Jepang yaitu Toshiba. Akuntan independen dan pengacara perusahaan Toshiba tersebut menyatakan laba operasional Toshiba telah dibesar-besarkan sebesar ¥ 151.8 milyar atau sekitar US\$ 1,22 miliar. Aktivitas tersebut dapat mempengaruhi kualitas laba. Temuan ini diharapkan mengarah pada penyajian kembali laporan laba, dan berpotensi mengalami denda yang sangat besar atas skandal tingkat terburuk di Jepang sejak Olympus Corp ditemukan menutupi kerugian US\$ 1,7 miliar (Liputan6.com, 2015). Skandal manipulasi keuangan tersebut dilakukan dengan tujuan agar kinerja perusahaan terlihat baik kemudian diiringi dengan peningkatan nilai perusahaan yang pada akhirnya akan berdampak pada besarnya bonus bagi manajemen.

Menurut hasil penelitian Wah (2002), perusahaan dengan investment opportunity set yang tinggi lebih mungkin untuk mempunyai discretionary accrual (akrual kelolaan) yang tinggi. Hasil ini mengindikasikan bahwa tujuan utama perusahaan melakukan manipulasi discretionary accrual adalah untuk menghasilkan investment opportunity set yang tinggi. Investment Opportunity Set (IOS) merupakan suatu kombinasi antara aktiva yang dimiliki (asset in place) dan pilihan investasi di masa yang akan datang dengan net present value positif.

Menurut Gaver dan Gaver (1993) dalam Hasnawati (2005:118), IOS merupakan nilai perusahaan yang besarnya tergantung pada pengeluaran-pengeluaran yang ditetapkan manajemen dimasa yang akan datang, dimana pada saat ini merupakan pilihan-pilihan investasi yang diharapkan akan menghasilkan 
return yang besar. Secara umum dapat dikatakan bahwa IOS menggambarkan tentang luasnya kesempatan atau peluang investasi bagi suatu perusahaan, namun sangat tergantung pada pilihan expenditure perusahaan untuk kepentingan di masa yang akan datang. Hasnawati (2005:117) memperkenalkan set peluang investasi (investment opportunity set) dalam kaitannya untuk mencapai tujuan perusahaan. Menurutnya IOS memberikan petunjuk yang lebih luas dimana nilai perusahaan sebagai tujuan utama tergantung pada pengeluaran perusahaan di masa yang akan datang.

Keputusan investasi yang dibuat oleh manajemen akan mempengaruhi cara pandang investor dan pemilik perusahaan sehingga mempengaruhi nilai perusahaan. Pengaruh IOS pada nilai perusahaan didasarkan pada signaling theory dimana perusahaan akan memberikan sinyal positif terhadap investor, sehingga investor akan memberikan respon yang positif pula terhadap perusahaan yang memiliki IOS tinggi, karena lebih menjanjikan return di masa yang akan datang.

Investor yang menyukai risiko (risk taker) biasanya telah mengerti bahwa return yang tinggi akan diikuti dengan tingkat risiko yang tinggi pula. Kepercayaan investor terhadap perusahaan yang mengambil kebijakan investasi dalam jumlah yang tinggi, akan mengakibatkan naiknya permintaan saham perusahaan. Sinyal positif akan diberikan melalui peluang investasi yang berkaitan dengan pertumbuhan perusahaan di masa yang akan datang, sehingga dapat meningkatkan harga saham sebagai indikator nilai perusahaan. Hal ini didukung oleh penelitian (Rachmawati dan Triatmoko 2007), dan (Prastika 2013) yang membuktikan bahwa IOS berpengaruh positif terhadap nilai perusahaan. Penelitian lainnya yang dilakukan oleh Yuliariskha (2012) menemukan hasil yang berbeda yaitu IOS tidak berpengaruh terhadap nilai perusahaan.

Menurut hasil penelitian Wah (2002), perusahaan dengan investment opportunity yang tinggi lebih mungkin untuk mempunyai discretionary accrual yang tinggi sehingga hal ini dapat mempengaruhi kualitas laba. Beberapa penelitian menunjukkan bahwa kualitas laba akan mempengaruhi respon pasar terhadap laba perusahaan (Choi dan Jeter, 1990). Perusahaan dengan investment opportunity yang tinggi lebih mungkin untuk mempunyai discretionary accrual yang tinggi sehingga akan mempengaruhi 
persepsi pasar terhadap kualitas laba. Persepsi pasar terhadap suatu perusahaan pada akhirnya akan mempengaruhi harga saham perusahaan tersebut dan akan berdampak pada nilai perusahaan.

Berdasarkan latar belakang, peneliti ingin menguji kembali pengaruh IOS pada nilai perusahaan dengan kualitas laba sebagai variabel moderasi. Adapun tujuan penelitian ini yaitu, 1) untuk mendapatkan bukti empiris mengenai pengaruh IOS pada nilai perusahaan; 2) untuk mendapatkan bukti empiris mengenai pengaruh IOS pada nilai perusahaan dengan kualitas laba sebagai variabel moderasi. Kegunaan penelitian antara lain, kegunaan teoretis dan kegunaan praktis. Kegunaan teoretis artinya dapat dijadikan sebagai pembuktian yang dapat memperkuat teori yang sudah ada yaitu teori sinyal dan teori keagenan. Selain itu juga dapat mendukung dan memberikan kontribusi pengembangan ilmu pengetahuan yang berkaitan dengan IOS, kualitas laba, dan nilai perusahaan. Kegunaan praktis artinya dapat dijadikan sebagai alat bantu pengambilan keputusan bagi para pemilik modal yang ingin bernvestasi pada perusahaan manufaktur.

\section{TINJAUAN PUSTAKA DAN PERUMUSAN HIPOTESIS}

Penelitian ini menggunakan teori keagenan dan teori sinyal. Teori Keagenan memaparkan keterkaitan antara manajemen dengan principal didalam proses pengelolaan perusahaan. Menurut Jensen dan Meckling (1976), teori ini menyiratkan adanya suatu pemberian wewenang dari pihak principal kepada agen melalui pendelegasian otoritas, dimana agen diharapkan dapat mengambil keputusan terbaik dalam upaya pemecahan masalah.

Signalling theory yang lebih ditekankan adalah pentingnya laporan yang disajikan oleh perusahaan untuk dijadikan pengambilan keputusan dalam berinvestasi bagi para investor. Informasi menjadi poin yang krusial bagi pengambil keputusan dan pebisnis karena informasi pada dasarnya memberikan gambaran kondisi perusahaan terdahulu, sekarang dan di masa depan bagaimana kelangsungan hidup perusahaan dan harga sahamnya. Alat pengambilan keputusan bagi investor dalam pasar modal yang paling dibutuhkan ialah informasi yang rinci, akurat, dan tepat waktu.

Investment Opportunity Set (IOS) dengan net present value positif merupakan gabungan antara suatu 
pilihan investasi di masa depan dengan aktiva yang dimiliki. IOS merupakan banyaknya jumlah pengeluaran yang ditentukan pihak pengelola perusahaan di masa depan dengan menempatkan dana pada pilihan investasi bertujuan untuk memperoleh feed back tinggi yang nantinya akan berdampak pada besanya nilai perusahaan (Gaver dan Gaver, 1993) dalam Hasnawati (2005: 118). Pada umumnya IOS dikatakan suatu gambaran mengenai pilihan investasi perusahaan, tergantung pada pilihan pengeluaran perusahaan guna memenuhi keperluan perusahaan pada masa mendatang.

Kualitas laba, menurut Schipper dan Vincent (2003), menunjukkan tingkat kedekatan laba yang dilaporkan dengan Hicksian income, yang merupakan laba ekonomik yaitu jumlah yang dapat dikonsumsi dalam satu periode dengan menjaga kemampuan perusahaan pada awal dan akhir perioda tetap sama. Menurut Schipper dan Vincent (2003), kualitas laba akuntansi ditunjukkan oleh kedekatan atau korelasi antara laba akuntansi dan laba ekonomik (Suwardjono, 2006: 463).

Menurut Husnan (2000: 7) nilai perusahaan merupakan harga yang bersedia dibayar oleh calon pembeli apabila perusahaan tersebut dijual atau dapat diartikan sebagai harga pasar atas perusahaan itu sendiri. Pengukuran nilai perusahaan (corporate value) dalam penelitian kali ini akan menggunakan pendekatan konsep nilai pasar yang mengacu pada penelitian Fama (1978), serta Soliha dan Taswan (2002).

\section{Investment Opportunity Set (IOS) dan Nilai Perusahaan}

Dalam teori manajemen keuangan, ada trade-off antara risiko dan return. Jika risiko suatu investasi lebih tinggi, return yang diharapkan juga tinggi dan banyak para manajer mengetahui risiko untuk dipertimbangkan dalam menilai dan mangambil keputusan investasi. Penilaian dan pemahaman trade-off antara risiko dan return membentuk landasan untuk memaksimumkan kesejahteraan pemegang saham. Secara umum investor enggan terhadap risiko (overse risk). Jika risiko lebih besar, investor mengharapkan return yang lebih besar. Return yang tinggi tidak selalu disertai investasi berisiko. Investasi yang berisiko tidak akan dilakukan oleh investor jika investasi tersebut tidak memberi harapan tingkat return yang tinggi atau nilai perusahaan yang baik. Dengan demikian banyak perusahaan melakukan investasi yang menguntungkan bagi perusahaan tentunya dengan memilih 
risiko yang terkecil, hal ini akan bertujuan untuk mencapai tujuan perusahaan dalam mencapai profitabilitas yang nantinya jika profitabilitas tercapai akan dapat membagikan deviden yang besar, dan secara tidak langsung harga saham naik, dan tentunya berpengaruh pada naiknya nilai perusahaan. Penelitian yang dilakukan oleh Adriani (2011) dan Astriani (2014) menunjukkan bahwa investment opportunity set mempunyai pengaruh positif terhadap nilai perusahaan. Dengan demikian keterkaitan antara investment opportunity set (IOS) dengan nilai perusahaan dapat dirumuskan melalui hipotesis sebagai berikut:

$\mathrm{H}_{1}$ : Investment Opportunity Set (IOS) berpengaruh positif pada nilai perusahaan.

\section{Kualitas Laba, Investment Opportunity Set (IOS) dan Nilai Perusahaan}

Perusahaan yang memiliki kualitas laba yang bagus cenderung akan menyebabkan Investment Opportunity Set (IOS) perusahaan meningkat sehingga meningkatkan nilai perusahaan. Penelitian yang dilakukan oleh (Paulus 2012) menemukan bahwa kualitas laba berpengaruh terhadap IOS. Syifa (2015) menyatakan bahwa dalam penelitiannya IOS mempunyai pengaruh positif pada nilai perusahaan. Berdasarkan uraian di atas, maka hipotesis yang dapat diajukan adalah:

$\begin{array}{rlr}\mathrm{H}_{2}: & \text { Kualitas Laba Memperkuat } \\ & \text { Hubungan Investment } \\ & \text { Opportunity Set (IOS) Pada Nilai } \\ & \text { Perusahaan. }\end{array}$

\section{METODA PENELITIAN}

Cakupan penelitian ini terbatas pada pengaruh IOS, kualitas laba, dan nilai perusahaan. Variabelvariabel yang diuji dapat dibagi antara lain: (1) Variabel terikat (Y) yang dipakai dalam penelitian ini nilai perrusahaan. (2) Variabel bebasnya (X) antara lain Investment Opportunity Set (IOS). 3) Variabel moderasinya adalah kualitas laba. IOS merupakan jumlah pengeluaran yang dibuat oleh pihak manajemen di periode berikutnya dengan menempatkan dana pada pilihan investasi bertujuan untuk memperoleh feed back tinggi yang nantinya akan berdampak pada besarnya nilai perusahaan (Gaver dan Gaver, 1993) dalam Hasnawati (2005: 118). Proksi yang dipakai sebagai alat ukur IOS ialah market value to book value of assets. Nilai perusahaan adalah cerminan dari harga saham yang dinilai oleh pasar melebihi nilai bukunya memberikan citra baik bagi perusahaan. Proksi yang digunakan mengukur ialah $P B V$. Menurut Kawatu (2009) bahwa Price to Book 
Value $(P B V)$ menggambarkan seberapa besar pasar menghargai nilai buku saham suatu perusahaan. Semakin tinggi rasio ini, berarti pasar percaya akan prospek perusahaan tersebut. Kualitas laba sebagai perbedaan antara laba dilaporkan dengan laba yang sebenarnya Chandrarin (2001). Proksi kualitas laba yang digunakan untuk mengukur adalah discretionary accruals (DACC).

Perusahaan manufaktur periode 2011-2015 merupakan tempat dilakukannya penelitian ini. Penelitian ini memakai data sekunder dalam bentuk annual report perusahaan manufaktur yang telah teracatat di BEI periode 2011-2015. Data tersebut didapatkan dengan cara mengunduh laporan tahunan melalui web resmi BEI. Investment opportunity set digunakan sebagai variabel bebas, nilai perusahaan sebagai variabel terikat, dan kualitas laba sebagai variabel moderasi. Seluruh perusahaan manufaktur yang terdacatat di BEI periode 20112015 sejumlah 121 perusahaan dijadikan populasi dalam penelitian ini. Dari jumlah populasi tersebut sampel yang diambil dengan purposive sampling menjadi sebanyak 38 perusahaan.

Penelitian ini dianalisis menggunakan dua uji yaitu: 1) uji asumsi klasik, 2) uji Moderated
Regression Analysis (MRA).. Adapun model persamaan regresinya adalah sebagai berikut :

$$
\begin{aligned}
Y=a & +\beta_{1} X_{1}+\beta_{2} X_{2} X_{3}+\varepsilon_{1} \ldots \ldots \ldots \ldots \ldots . . .(1) \\
& \text { Keterangan: } \\
& Y=\text { Nilai Perusahaan } \\
& a=\text { Konstanta } \\
\beta & =\text { Koefisien regresi } \\
& \varepsilon=\text { Standar error } \\
& X 1=\text { Investment opportunity set } \\
& X 2=\text { Kualitas Laba } \\
& \text { Menurut Ghozali (2013: 97), }
\end{aligned}
$$
fungsi regresi sampel yang tepat dalam memperkirakan nilai sesungguhnya diukur dengan goodness of fit, yang terdiri dari beberapa bagian antara lain uji statistik F, dan nilai statistik t.

\section{HASIL DAN PEMBAHASAN}

\section{Analisis Statistika Deskriptif}

Statistik deskriptif bertujuan menggambarkan objek yang menjadi sampel yaitu IOS, NP, dan kualitas laba secara umum. Pada Tabel 1, hal yang dapat dipaparkan yaitu nilai maksimum yang tertinggi dimiliki oleh variabel nilai perusahaan sebesar 10,09, kedua variabel IOS sebesar 7,81 , ketiga variabel kualitas laba sebesar 0,91. Nilai minimum yang terendah dimiliki oleh variabel kualitas laba dan nilai perusahaan sebesar 0,00, dan nilai minimum tertinggi adalah variabel IOS sebesar 0,05. Nilai rata-rata pada Perusahaan 
Manufaktur dari variabel IOS fluktuasi kualitas laba pada menunjukkan sebesar 0,66 dengan perusahaan Manufaktur yang standar deviasi sebesar 0,80 dimana nilai standar deviasi lebih besar dari nilai rata-ratanya mengindikasikan adanya fluktuasi IOS pada Perusahaan Manufaktur yang menjadi sampel. Variabel kualitas laba nilai rata-ratanya menunjukkan sebesar 0,29 dengan standar deviasi sebesar 0,19 di mana nilai standar deviasi lebih kecil dari nilai ratamenjadi sampel. Nilai rata-rata pada Perusahaan Manufaktur dari variabel nilai perusahaan menunjukkan sebesar 1,02 dengan standar deviasi sebesar 1,81 di mana nilai standar deviasi lebih besar dari nilai rataratanya mengindikasikan adanya fluktuasi nilai perusahaan pada perusahaan Manufaktur yang menjadi sampel.

ratanya mengindikasikan tidak ada

Tabel 1 Hasil Statistik Deskriptif

\begin{tabular}{lccc}
\hline VARIABEL & IOS & KL & NP \\
\hline Maksimum & 7,81 & 0,91 & 10,09 \\
Minimum & 0,05 & 0,00 & 0,00 \\
Rata-rata & 0,66 & 0,29 & 1,02 \\
Deviasi Standar & 0,80 & 0,19 & 1,81
\end{tabular}

Sumber: Data diolah menggunakan aplikasi SPSS 21

\section{Uji Asumsi Klasik}

Uji asumsi klasik pada model menunjukkan bahwa datanya terbebas dari masalah normalitas dengan melihat nilai Asymp Sig (2tailed) sebesar 0,10 > 0,05. Nilai VIF dan nilai tolerance dari variabel bebas yaitu Investment Opportunity Set (IOS). Nilai VIF tidak lebih dari angka 10 dan nilai tolerance lebih dari angka 0,10 yaitu sebesar 1,60< 10 dan 0,62 $>0,10$. Hasil tersebut berarti bahwa bebas dari masalah multikolonieritas.
Hasil uji heteroskedastisitas diuji dengan menggunakan uji glejser dimana jika hasil variabel independen tidak signifikan secara statistik tidak mempengaruhi variabel dependen. Hal tersebut berarti tidak terjadi heteroskedastisitas Ghozali (2011: 143). Hasil uji heteroskedastisitas dapat dilihat pada tabel 2 yang menunjukkan bahwa tidak ada satupun variabel independen yang signifikan secara statistik mempengaruhi variabel dependen 
nilai Absolut Ut (AbsUt). Hal ini terlihat dari probabilitas signifikansinya di atas tingkat kepercayaan 5\%. Maka dapat disimpulkan model regresi tidak mengandung heteroskedastisitas. Berdasarkan pengujian tersebut dapat disimpulkan bahwa persamaan regresi dalam penelitian ini telah lolos pengujian asumsi klasik.

Tabel 2 Hasil Uji Heteroskedastisitas

\begin{tabular}{crrrr}
\hline Variable & Coefficient & Std. Error & t-Statistic & Prob. \\
\hline \hline C & 0,300 & 0,040 & 7,466 & 0,000 \\
NP & $-0,028$ & 0,016 & $-1,780$ & 0,077 \\
INTERAKSI & $-0,017$ & 0,024 & $-0,737$ & 0,462 \\
\hline
\end{tabular}

Sumber: Data diolah menggunakan aplikasi SPSS 21

\section{Moderated Regression Analysis (MRA)}

Pada tabel 3 ditunjukkan bahwa nilai konstanta sebesar -0,036 memiliki arti bahwa bila semua variabel independennya konstan, maka nilai perusahaan (Y) yang diproksikan dengan price to book value $(\mathrm{PBV})$ meningkat senilai -0,036 satuan. Koefisien regresi IOS bernilai negatif sebesar -0,512 menyatakan bahwa setiap kenaikan IOS sebesar $1 \%$ tidak akan menyebabkan penurunan atau kenaikan pada nilai perusahaan sebesar $51 \%$ dengan asumsi variabel independen lainnya tetap. Koefisien regresi interaksi IOS dan Kualitas laba bernilai positif sebesar 0,700 mempunyai makna bahwa interaksi IOS dan kualitas laba memperkuat pengaruh IOS pada nilai perusahaan sehingga ketika nilai interaksi meningkat 1\%, maka nilai perusahaan meningkat sebesar $70 \%$ dengan asumsi variabel independen lainnya tetap.

Tabel 3 Hasil Uji Moderated Regression Analysis

\begin{tabular}{crrrrr}
\hline \multirow{2}{*}{ Model } & \multicolumn{2}{c}{$\begin{array}{c}\text { Unstandardized } \\
\text { Coefficientst }\end{array}$} & $\begin{array}{c}\text { Standardized } \\
\text { Coefficients }\end{array}$ & t-Statistic & \multirow{2}{*}{ Prob. } \\
\cline { 2 - 3 } & B & Std. Error & Beta & & \\
\hline \hline C & $-0,036$ & 0,336 & & $-0,106$ & 0,915 \\
IOS & $-0,512$ & 0,264 & $-0,183$ & $-1,941$ & 0,054 \\
INTERAKSI & 0,700 & 0,169 & 0,390 & 4,128 & 0,000
\end{tabular}

Sumber: Data diolah menggunakan aplikasi SPSS 21 
Pengujian kelayakan model penelitian yang dilakukan dengan uji F (F test) untuk mengetahui apakah model regresi moderasi yang digunakan layak atau tidak. Hasil uji F yang signifikan menunjukkan bahwa variabel independen mempengaruhi variabel dependen dan model layak. Hasil uji $F$ pada penelitian ini ditampilkan pada Tabel 4. sebagai berikut.

Tabel 4 Hasil Uji F

\begin{tabular}{lc}
\hline F-statistic & 8.810 \\
\hline Prob(F-statistic) & .000 \\
\hline
\end{tabular}

Berdasarkan hasil uji $\mathrm{F}$ pada Tabel 4 diatas menunjukkan bahwa model layak dan variabel bebas secara serempak mempunyai pengaruh pada nilai perusahaan. Hal tersebut ditunjukkan oleh nilai $\mathrm{F}$ sebesar 8,810 dengan signifikansi 0,000 yang berada di bawah nilai
0,05 .

Uji $t$ digunakan untuk mengetahui seberapa jauh pengaruh variabel penjelas atau independen secara individual menerangkan variasi variabel dependen. Hasil uji $t$ dapat dilihat pada tabel 5 berikut.

Tabel 5 Hasil Uji t

\begin{tabular}{cccccc}
\hline \multirow{2}{*}{ Model } & \multicolumn{2}{c}{$\begin{array}{c}\text { Unstandardized } \\
\text { Coefficientst }\end{array}$} & $\begin{array}{c}\text { Standardized } \\
\text { Coefficients }\end{array}$ & t-Statistic & \multirow{2}{*}{ Prob. } \\
\cline { 2 - 4 } & B & Std. Error & Beta & & \\
\cline { 2 - 4 } C & $-0,036$ & 0,336 & & $-0,106$ & 0,915 \\
IOS & $-0,512$ & 0,264 & $-0,183$ & $-1,941$ & 0,054 \\
INTERAKSI & 0,700 & 0,169 & 0,390 & 4,128 & 0,000
\end{tabular}

Sumber: Data diolah menggunakan aplikasi SPSS 21

Hasil uji t pada Tabel 5 di atas menunjukkan bahwa variabel IOS $\left(\mathrm{X}_{1}\right)$ memiliki nilai t hitung senilai $-1,941$ dan nilai signifikansinya senilai 0,054. Nilai signifikansinya senilai 0,054 lebih besar dari nilai tingkat signifikansi 0,05 berarti IOS $\left(\mathrm{X}_{1}\right)$ yang diukur menggunakan MBVA secara parsial tidak berpengaruh pada nilai perusahaan $(\mathrm{Y})$.

Variabel interaksi IOS dengan kualitas laba memiliki nilai t hitung 
senilai 4,128 dan nilai signifikansinya senilai 0,000 . Nilai signifikansinya senilai 0,000 lebih kecil dari nilai tingkat signifikansi 0,05 berarti kualitas laba $\left(\mathrm{X}_{2}\right)$ yang diproksikan menggunakan DACC mampu memoderasi pengaruh IOS $\left(\mathrm{X}_{1}\right)$ pada nilai perusahaan $(\mathrm{Y})$.
Analisis Koefisien Determinasi (R2) menunjukkan seberapa besar variabel dependen dapat dijelaskan oleh variabel independen. Pada penelitian ini hasil analisis koefisien determinasi dapat dilihat pada Tabel 6 sebagai berikut.

Tabel 6 Hasil Analisis Koefisien Determinasi $\left(R^{2}\right)$

\begin{tabular}{ll}
\hline Adjusted $R$ Square & 0,086 \\
\hline Std. Error of the Estimate & 1,86328
\end{tabular}

Sumber: Data diolah menggunakan aplikasi SPSS 21

Berdasarkan Tabel 6, dapat diketahui bahwa nilai Adjusted $R$ squared sebesar 0,086, nilai tersebut mempunyai arti bahwa variasi nilai perusahaan yang diukur menggunakan $P B V$ dapat dijelaskan oleh variasi variabel indenpenden IOS dan interaksi IOS dengan Kualitas laba sekitar $8,6 \%$ dan sisanya sebesar 91,4\% dijelaskan oleh variabel lain diluar model.

Berdasarkan hasil uji MRA pada Tabel 3, IOS yang diukur menggunakan MBVA mempunyai koefisien regresi senilai -0,512 dan hitung senilai $-1,941$ dengan nilai signifikansinya senilai 0,054 lebih besar dari tingkat signifikansi 5\% menunjukkan, IOS tidak berpengaruh signifikan pada nilai perusahaan, $\left(\mathrm{H}_{1}\right.$ ditolak). Hasil penelitian sejalan dengan hasil penelitian Sholichah
(2015) yang menyatakan bahwa IOS tidak berpengaruh signifikan pada nilai perusahaan. Hal ini menunjukkan bahwa sinyal pertumbuhan perusahaan yang tercermin dalam level IOS tinggi tidak direspon oleh para pelaku pasar dengan sikap berbeda dengan perusahaan yang tidak tumbuh (level IOS rendah) dalam mengambil keputusan Syifa (2015). Hal ini disebabkan oleh beberapa faktor yaitu; 1) Karena investor tidak selalu memperhatikan IOS perusahaan dalam berinvestasi karena investor menganggap investasi aset pada perusahaan tidak akan menjamin bahwa pertumbuhan perusahaan tersebut akan bagus di masa mendatang dan meningkatkan nilai perusahaan. 2) Karena tidak semua para pelaku pasar menggunakan 
informasi laporan keuangan secara cermat dalam mengambil keputusan, bahkan tidak menutup kemungkinan mereka hanya mengandalkan analisis teknikal dan lain sebagainya.

Hasil uji MRA yang ditunjukkan pada Tabel 3, variabel interaksi IOS dengan kualitas laba memiliki koefisien regresi moderasi sebesar 0,700 dengan nilai $t$ hitung yang dimiliki sebesar 4,128 dan nilai signifikansi sejumlah 0,000 yang lebih kecil dari tingkat signifikansi 5\% menunjukkan, kualitas laba mampu memoderasi pengaruh IOS pada nilai perusahaan secara positif signifikan, $\left(\mathrm{H}_{2}\right.$ diterima). Arah positif menunjukkan bahwa kualitas laba mampu memperkuat pengaruh IOS pada nilai perusahaan. Hal ini karena investor yang berinvestasi pada Perusahaan Manufaktur tidak cukup hanya melihat IOS untuk memprediksi pertumbuhan suatu perusahaan tetapi investor juga melihat kualitas laba. Apabila kualitas laba yang dilaporkan suatu perusahaan itu relatif bagus maka nilai perusahaan juga akan ikut meningkat dan investor akan lebih yakin untuk menginvestasikan dananya pada Perusahaan Manufaktur. Oleh karena itu, kualitas laba memperkuat pengaruh IOS pada nilai perusahaan.

\section{KESIMPULAN IMPLIKASI DAN KETERBATASAN PENELITIAN}

Menurut teori, hipotesis dan temuan penelitian maka beberapa kesimpulan dapat dibuat yaitu: (1) Investment Opportunity Set tidak mempunyai pengaruh pada nilai perusahaan, (2) Kualitas laba mampu memperkuat pengaruh investment opportunity set pada nilai perusahaan.

Hasil penelitian ini dapat memberikan implikasi baik kepada kalangan akademis dan praktisi. Bagi kalangan akademis penelitian ini dapat menambah wawasan, pengetahuan mengenai kualitas laba memoderasi pengauh IOS pada nilai perusahaan Manufaktur dan dapat digunakan sebagai acuan dalam penelitian sejenis, serta hasil penelitian ini dapat dijadikan bahan kajian teoretis dan refrerensi. Bagi para praktisi penelitian ini dapat dijadikan gambaran dalam pengambilan keputusan untuk berinvestasi pada perusahaan Manufaktur karena IOS terbukti berpengaruh pada nilai perusahaan yang diperkuat oleh kualitas laba.

Berdasarkan hasil penelitian maka dapat disebutkan bahwa penelitian ini memiliki keterbatasan yaitu penelitian ini hanya berfokus pada perusahaan manufaktur yang terdaftar di BEI pada tahun 20112015. Berdasarkan keterbatasan 
tersebut maka dapat disarankan penelitian selanjutnya diharapkan menggunakan perusahaan yang berbeda dengan penelitian ini dan rentang periode pengamatan yang lebih panjang sehingga sampel yang didapatkan bisa lebih banyak dan hasil penelitian lebih baik serta dapat memasukkan variabel kontrol dalam model penelitian. Penelitian selanjutnya juga bisa mengembangkan penelitian ini dengan menggunakan proksi yang berbeda untuk semua variabel dalam penelitian ini.

\section{REFERENSI}

Adriani, Irma. 2011. "Pengaruh Investment Opportunity Set Dan Mekanisme Corporate Governance Terhadap Kualitas Laba Dan Nilai Perusahaan." Universitas Diponegoro.

Astriani, Eno Fuji. 2013. "Pengaruh Kepemilikan Manajerial, Leverage, Profitabilitas, Ukuran Perusahaan Dan Investment Opportunity Set Terhadap Nilai Perusahaan." Negeri Padang.

Belkaoui, A. R. 2003. "Intellectual Capital and Firm Performance of US Multinational Firms: A Study of The Resource-Based and Stakeholder Views." Journal of Intellectual Capital Vol. 4 (No. 2): 215-26.

Chandrarin, G. 2001. "Laba (Rugi) Selisih Kurs Sebagai Salah Satu Faktor Yang Mempengaruhi Koefisien Respon Laba Akuntansi: Bukti Empiris Dari
Pasar Modal Indonesia." Universitas Gadjah Mada.

Choi, S dan Jeter, C.D. 1990. "The Effect of Qualifield Audit Opinions on Earnings Responses Coefficients." Of Accounting and Economics Vol.15: pp 229-247.

Fahmi, Irham. 2012. Pengantar Pasar Modal. Bandung: CV Alfabeta.

Fama, E. F. 1978. "The Effect of a Firm's Investment and Financing Decision on the Welfare of Its Security Holders." American Economic Review, no. 68(3): 27228.

Ghozali, Imam. 2011. Aplikasi Analisis Multivariate Dengan Program IBM SPSS 19. Edisi 5. Semarang: Badan Penerbit Universitas Diponegoro.

2013. Analisis Multivariat Dan Ekonometrika, Teori, Konsep, Dan Aplikasi Dengan EViews ${ }^{\circledR}$. Semarang: Badan Penerbit Universitas Diponegoro.

Hasnawati, Sri. 2005. "Implikasi Keputusan Investasi, Pendanaan, Dan Deviden Terhadap Nilai Perusahaan Publik Di Bursa Efek Jakarta." In , No.09/Th Xxxix. Jakarta.

Husnan, Suad. 2000. Manajemen Keuangan Dan Penerapan (Keputusan Jangka Panjang). Yogyakarta: BPFE.

Jensen, Michael C. dan W. H. Meckling. 1976. "Theory of the Firm: Managerial Behaviour, Agency Cost and Ownership Structure." Journal of Financial EconomICs Vol. 3 (4): 305-60. 
Kawatu, Freddy Semuel. 2009. "Mekanisme Corporate Governance Terhadap Nilai Perusahaan Dengan Kualitas Laba Sebagai Variabel Intervening." Jurnal Keuangan Dan Perbankan Vol.13 (No.13): pp 405-417.

Paulus, Christian. 2012. "Analisis Faktor-Faktor Yang Mempengaruhi Kualitas Laba." Jurnal Ekonomika Dan Bisnis Universitas Diponegoro, no. 3.

Prastika, Ni Gst. A. Pt. Silka. 2013. "Pengaruh IOS, Leverage, Dan Dividend Yield Terhadap Profitabilitas Dan Nilai Perusahaan Sektor Manufaktur Di BEI." Jurnal Ekonomi Dan Bisnis Universitas Udayana, no. 1: 147-74. https: / / doi.org/10.1017/CBO97 81107415324.004.

Rachmawati, Andri, and Hanung Triatmoko. 2007. "Ananlisis Faktor-Faktor Yang Mempengaruhi Kualitas Laba Dan Nilai Perusahaan." Simposium Nasioanal Akuntansi $X, 1-26$.

Salvatore, Dominick. 2011. Ekonomi Manajerial Dalam Perekonomian Global. Buku I Edi. Jakarta: Salemba Empat.

Schipper K. and L. Vincent. 2003. "Earnings Quality. Accounting Hoorizon." Suplement, 97-110.

Sholichah, Nur. 2015. "Pengaruh Ukuran Perusahaan, Investment Opportunity Set (IOS), Dan Corporate Governance Terhadap Kualitas Laba Pada Perusahaan Yang Terdaftar Di Jakarta Islamix Indek (JII) Periode 2010-2014." Jurnal Manajemen Keuangan.
Soliha, E. dan Taswan. 2002. "Pengaruh Kebijakan Hutang Terhadap Nilai Perusahaan Serta Beberapa Faktor Yang Mempengaruhinya." Jurnal Bisnis Dan Ekonomi. 2002. www.google.com.

Suwardjono. 2006. Teori Akuntansi: Perekayasaan Pelaporan Keuangan. Edisi Keti. Yogyakarta: BPFE.

Syifa, Sufi Fajrotus. 2015. "Pengaruh Investment Opportunity Set (IOS), Kepemilikan Institusional, Komisaris Independen, Dan Return On Investment (ROI) Terhadap Nilai Perusahaan Pada Perusahaan Manufaktur Yang Terdaftar Di Bursa Efek Indonesia." Universitas Negri Yogyakarta.

Wah, Lai Kam. 2002. "Investment Opportunity and Audit Quality." Journal of Accounting and Public Policy, no. No. 28: pp.33 - 50.

Yuliariskha, Fania. 2012. "Pengaruh Keputusan Pendanaan, Keputusan Investasi Serta Kebijakan Dividen Terhadap Nilai Perusahaan (Studi Pada Perusahaan Manufaktur Yang Terdaftar Di BEI Periode 20082010)." Universitas Brawijaya. 